$\mathbb{T}$ periodica polytechnica

Mechanical Engineering

$52 / 2(2008) 6166$

doi: 10.3311/pp.me.2008-2.04

web: http://www.pp.bme.hu/me

(c) Periodica Polytechnica 2008

RESEARCH ARTICLE

\section{Analysis of energy consumption of air handling units based on probability theory}

\author{
László Kajtár / Miklós Kassai
}

Received 2008-01-18

\begin{abstract}
The existing building stock in Hungary accounts for over $40 \%$ of total energy consumption of which heating and airconditioning systems use represents the most. International and national regulations encourage cutting down the energy consumption in buildings. For this reason it is important to determine energy consumption exactly. In view of outdoor air parameters (temperature, humidity and enthalpy) variation a new calculation method was necessary to set up for evaluating of energy consumption of air handling units. In consideration of the fact that outdoor air condition values can be regarded as a probability variable we have worked out a new evaluation method of energy consumption of air handling units based on probability theory. The research work was carried out by scientific methods.
\end{abstract}

\section{Keywords}

Air handling units · energy consumption · probability theory

\section{László Kajtár}

Department of Building Service Engineering and Process Engineering, BME, H-1111 Budapest, Bertalan Lajos street 4-6, Hungary

e-mail: kajtar@epgep.bme.hu

\section{Miklós Kassai}

Department of Building Service Engineering and Process Engineering, BME, H-1111 Budapest, Bertalan Lajos street 4-6, Hungary

e-mail:kas.miklos@gmail.com

\section{Introduction}

The Directive 2002/91/EC of the European Parliament and Council on energy efficiency of buildings ordered to verify energy consumption of buildings, to cut down and certify the energy performance of buildings. Energy consumption of buildings depends on the HVAC systems to a higher degree such as air-conditioning systems.

7/2006. (V.24.) TNM order offers a direction about determination of energy consumption of the building and HVAC systems in Hungary. It provides a solution to determine energy consumption of HVAC systems during the year. This procedure is suitable to calculate annual energy consumption of heating and ventilating systems but in consequence of size limits determination of energy consumption of air-conditioning systems and air handling units have not ranged at large.

The aim of our research work was to work out a particular procedure. As outdoor air parameters (temperature, humidity and enthalpy) vary in daily and season period so vary the performance of heating, cooling and adiabatic humidifier constantly in the air handling unit [1]. The new scientific method that has been developed at Department of Building Service Engineering and Process Engineering in Budapest University of Technology and Economics considers outdoor climatic parameters (temperature, humidity, enthalpy) as probability variables [2]. Variation of outdoor air parameters were considered on the basis of distribution function of outdoor air temperature and enthalpy. The new physical and mathematical model takes into account the air handling processes during the operation of air handling units $[3,4]$. In order to put into practise the mathematical method a computer program was made to carry out a quick and exact calculation.

\section{Outdoor air condition as a probability variable}

From the perspective of air conditioning technology the key attributes of outdoor air are temperature, humidity and enthalpy. These values randomly vary from minute to minute. The probability theory starts from the bulk of the elementary results of some experiments (e.g.: air temperature measurement). One single real number can be attributed to each elementary event 
(the measured temperature). The correlation interpreted with this attribution is called the probability variable. We can talk about discrete and continuous distribution probability variable. The air condition values can take any value within a range and may be regarded as a continuous probability variable. A probability variable may have an expected value, dispersion, distribution and density function.

A probability variable with a continuous distribution is characterized by the distribution $(F(x))$ and density $(f(x))$ functions.

The probability that the value of probability variable is between $a$ and $b$ :

$$
P(a<x<b)=\int_{a}^{b} f(x) d x
$$

The distribution function shows the probability of $t$ probability variable taking a value less than $x$ :

$$
F(x)=P(t<x)
$$

The distribution functions of outdoor air parameters (temperature, enthalpy) can be applied for determine the actual energy consumption of air handling units [5]. The temperature, humidity and enthalpy of outdoor air can be accounted continuous distribution probability variable that can be converged as Gauss distribution [6].

Calculation of heating energy consumption it is necessary to take account of variation of outdoor air parameters (temperature, humidity and enthalpy) that vary in daily and season period [7, 8]. Making energy calculation of a building, the outdoor air condition values can be regarded as a probability variable [9] that has momentary, maximum, minimum and average values, distribution function which can be defined according daily, weekly, monthly and annual period. We can make more refinements by define a daytime period (07-19 hours) and a continuous operation (0-24 hours) of air handling units. Two distribution functions are shown in Fig. 1 and Fig. 2 in that a daytime (0719 hours) period and nightly period (19-07 hours) can be seen. Any point of functions shows the hours and the percentage of the term when temperature or enthalpy of outdoor air was lower than the examined point. It follows that the $\tau_{t o t}$ term which concerns to the $100 \%$ distribution is equal to the reference period. By integral calculation the air handling process is taken into account in Mollier enthalpy chart.

Integral always can be calculated by the area under the functions during determination of cooling and heating energy consumption. In view of annual energy consumption operational costs can be calculated by knowledge of power and heat cost.

\section{The physical and mathematical model}

An air handling unit contains two main groups of elements: supply and exhaust units. The main parts of an air handling unit: filter, heat recovery unit, pre-heater, re-heater, cooler, by-pass,

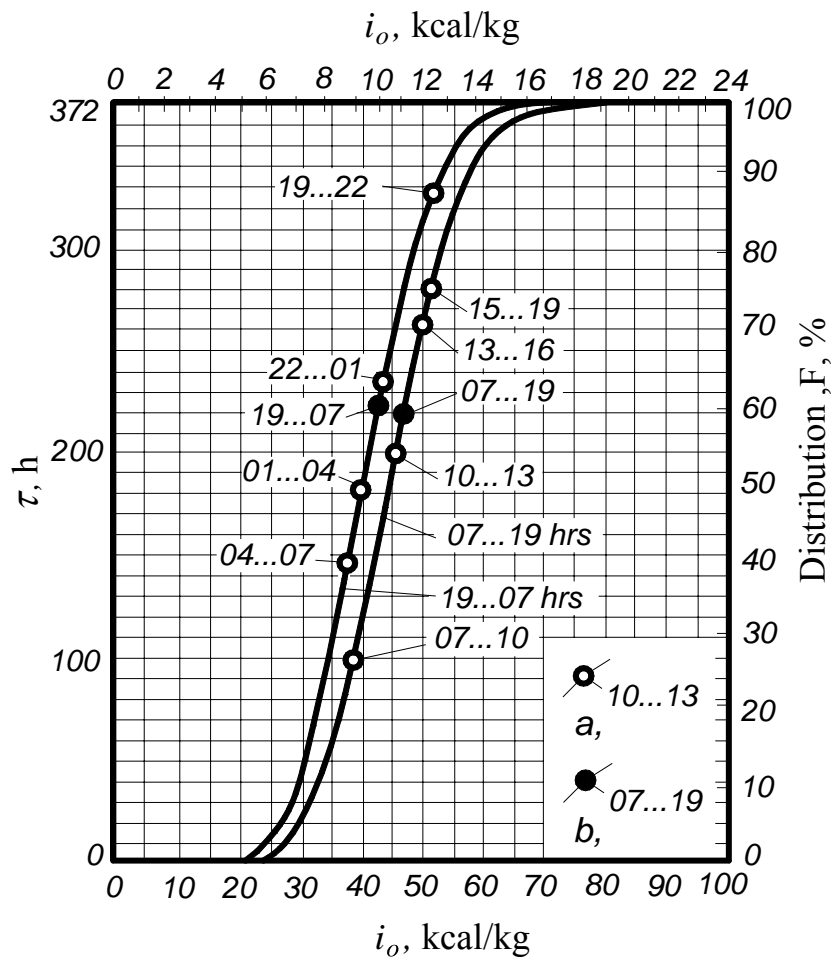

Fig. 1. The distribution function of outdoor air enthalpy in June (Budapest, average of measured temperatures between 1964-1972) [10]

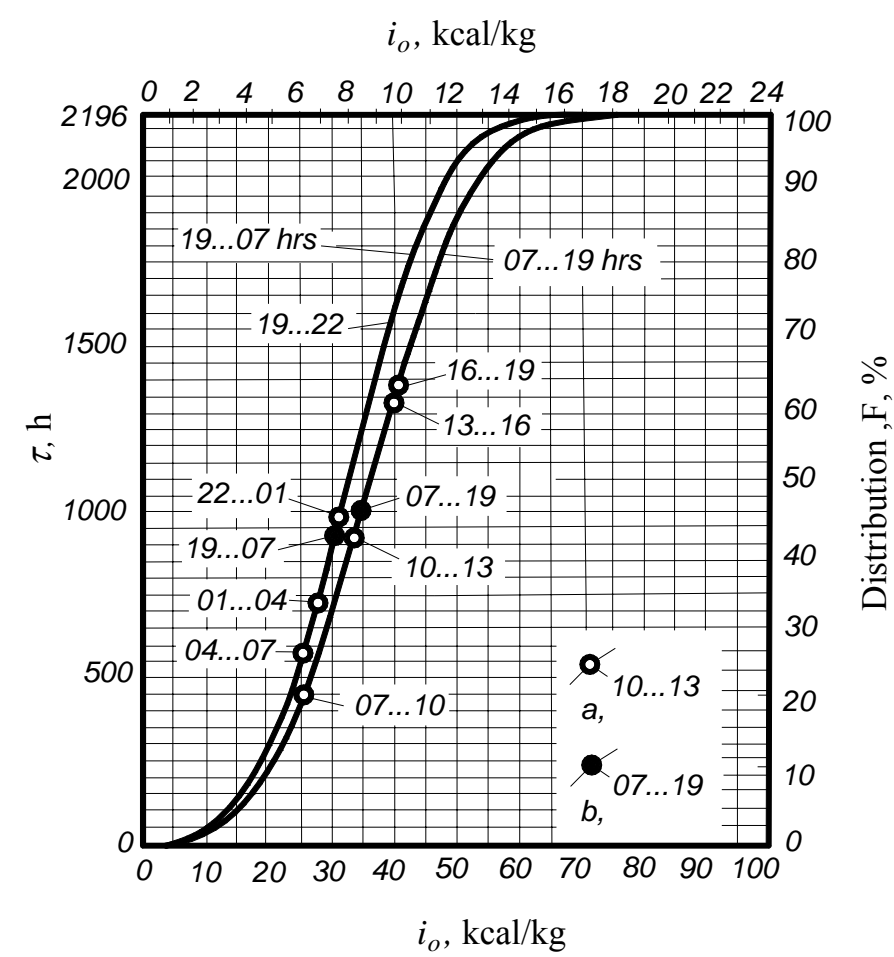

Fig. 2. The distribution function of outdoor air enthalpy from October until March (Budapest, average of measured temperatures between 1964-1972) [10]

adiabatic humidifier, fans [11,12]. In this article determination of heating energy consumption in winter time is published in the case of a few air handling units (AHUs) that are built up from the above-mentioned elements.

The general connecting diagram of AHUs is shown in Fig. 3 . Without heat recovery and by-pass a classical fresh air supplied AHU comes into being. 
Fig. 3. Connecting diagram of AHU

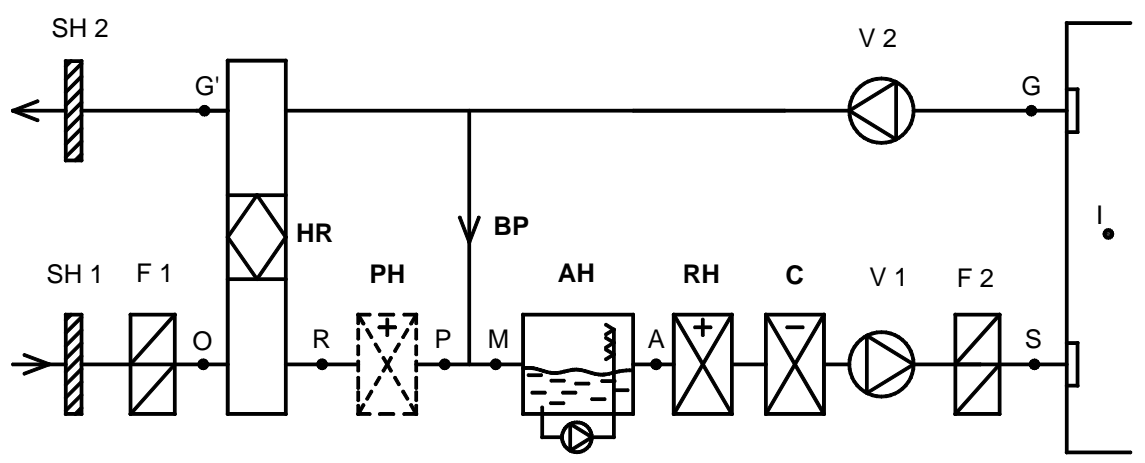

The signs of Fig. 3 are the followings:

3.1 Energy consumption of heaters:

$\begin{array}{ll}\mathrm{PH}: & \text { pre-heater } \\ \mathrm{RH}: & \text { re-heater } \\ \mathrm{C}: & \text { cooler }\end{array}$

$\mathrm{AH}$ : adiabatic humidifier

HR : heat recovery (cross flow heat exchanger $(\eta=0,72))$

$\mathrm{V}: \quad$ ventilator

BP : by-pass (for air recirculation)

F : filter

$\mathrm{SH}$ : $\quad$ shutter against the rain

Fig. 4 demonstrates the flowchart of four air handling units in Mollier enthalpy chart: a fresh air supplied AHU, with an air recirculation (BP) and adiabatic humidifier working AHU and both of them with heat recovery.

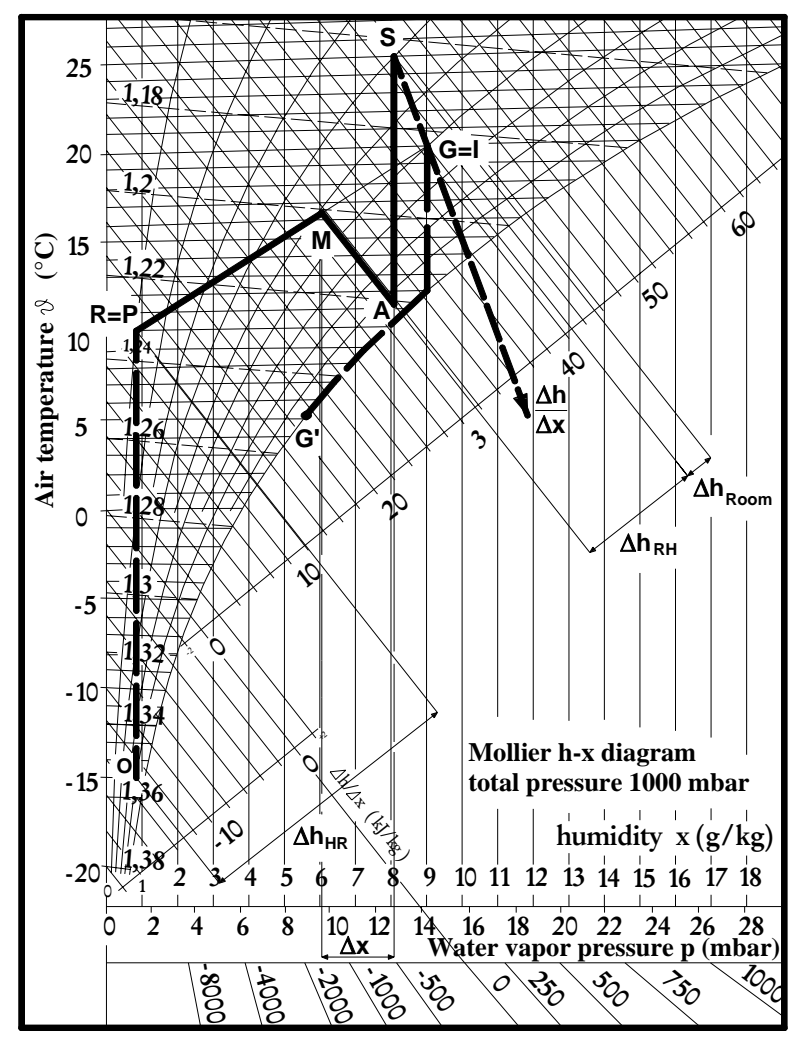

Fig. 4. Mollier $h-x$ flowchart of AHU

$$
Q_{H}=\rho \cdot c_{p a} \cdot \dot{V} \int_{-20}^{t_{H}} F\left(t_{o}\right) d t ; \quad \mathrm{kJ} / \text { year }
$$

where:

$\rho ; \mathrm{kg} / \mathrm{m}^{3}$
$c_{p a} ; \mathrm{kJ} / \mathrm{kg}^{\circ} \mathrm{C}$
$\dot{V} ; \mathrm{m}^{3} / \mathrm{h}$
$F\left(t_{0}\right):$

$t_{H} ; \quad{ }^{o} \mathrm{C}:$

\subsection{Energy consumption of fan:}

$$
W_{f a n}=\int \frac{\dot{V}_{S} \cdot \Delta p_{t f}}{\eta_{t f}} d \tau ; \mathrm{kJ} / \text { year }
$$

where:

$\dot{V}_{S} ; \mathrm{m}^{3} / \mathrm{h} \quad$ supply air flow rate delivered by fan

$\Delta P_{t f} ; \mathrm{Pa}$ the pressure loss of air handling unit

$\eta_{t f} ; \quad-\quad$ the total efficiency of the fan

\subsection{Energy consumption of pump:}

$$
W_{\text {pump }}=\int \frac{\dot{V}_{\text {water }} \cdot \Delta p_{t p}}{\eta_{t p}} d \tau ; \mathrm{kJ} / \text { year }
$$

where:

$\dot{V}_{\text {water }} ; \mathrm{m}^{3} / \mathrm{h} \quad$ supply water flow rate delivered by pump

$\Delta P_{t p} ; \mathrm{Pa} \quad$ lift of the pump

$\eta_{t p} ; \quad-\quad$ the total efficiency of the pump

Integration has to be calculated concerning the annual operation time. Peculiarities of AHUs working are continuous operation (0-24 hours) and intermittent operation (07-19 hours). During the energy consumption calculation of fan and pump integration can be determined easily thereby values of the working point data $\left(\dot{V}_{S}, \Delta P_{t f} ; \dot{V}_{w a t e r}, \Delta P_{t p}\right)$ are taken into consideration as constants. 
3.4 Fresh air supplied air handling unit with heat recovery, pre-heater and re-heater (FAS-HR AHU)

Operation parameters of AHU with pre-heater and re-heater are shown on the distribution function of outdoor air temperature from October until March in Fig. 5. The signs of the figure are the followings:

$$
\begin{aligned}
& F\left(t_{01}\right): \quad \text { temperature distribution function after heat } \\
& \text { recovery, } \\
& t_{R} ;{ }^{o} \mathrm{C}: \text { air temperature after the heat recovery }
\end{aligned}
$$

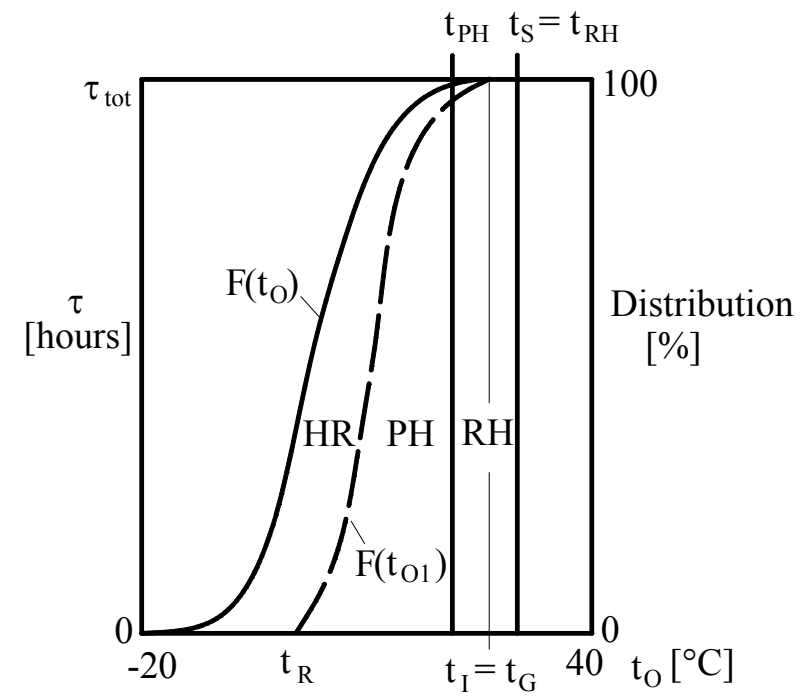

Fig. 5. Fresh air supplied air handling unit with heat recovery, pre-heater and re-heater in winter time (FAS AHU)

\section{Energy consumption of pre-heater:}

$$
Q_{P H}=\rho \cdot c_{p a} \cdot \dot{V} \int_{t_{R}}^{t_{P H}} F\left(t_{o 1}\right) d t ; \mathrm{kJ} / \text { year }
$$

\section{Energy consumption of re-heater:}

$$
Q_{R H}=\rho \cdot c_{p a} \cdot \dot{V} \int_{t_{P H}}^{t_{S}} F\left(t_{o 1}\right) d t ; \mathrm{kJ} / \text { year }
$$

The areas shown in Fig. 5 are proportional to energy consumption of the elements of air handling unit and the energy saving of heat recovery. In a similar way there is possibility to set up a physical and mathematical model of other air handling unit. $\tau_{\text {tot }}$ term which concerns to the $100 \%$ distribution has to be used for air handling units that are in continuous operation (024 hours). Distributions that apply to half day have to be used for air handling units that are in intermittent operation (07-19 hours). The areas which are shown in Fig. 5 are proportional to energy consumption of the elements of air handling unit $(\mathrm{PH}$, $\mathrm{RH})$ and the energy saving of heat recovery (HR).

3.5 Air handling unit with pre-heater, air recirculation, adiabatic humidifier and re-heater (REC-AH AHU)

The order of the air handling elements is: $\mathrm{PH}+\mathrm{BP}+\mathrm{AH}+$ $\mathrm{RH}$

The air temperature after the adiabatic humidifier $\left(\mathrm{t}_{A}\right)$ can be determined by winter air handling process on Mollier $\mathrm{h}-\mathrm{x}$ chart. Fig. 6 shows the energy consumption of air handling elements.

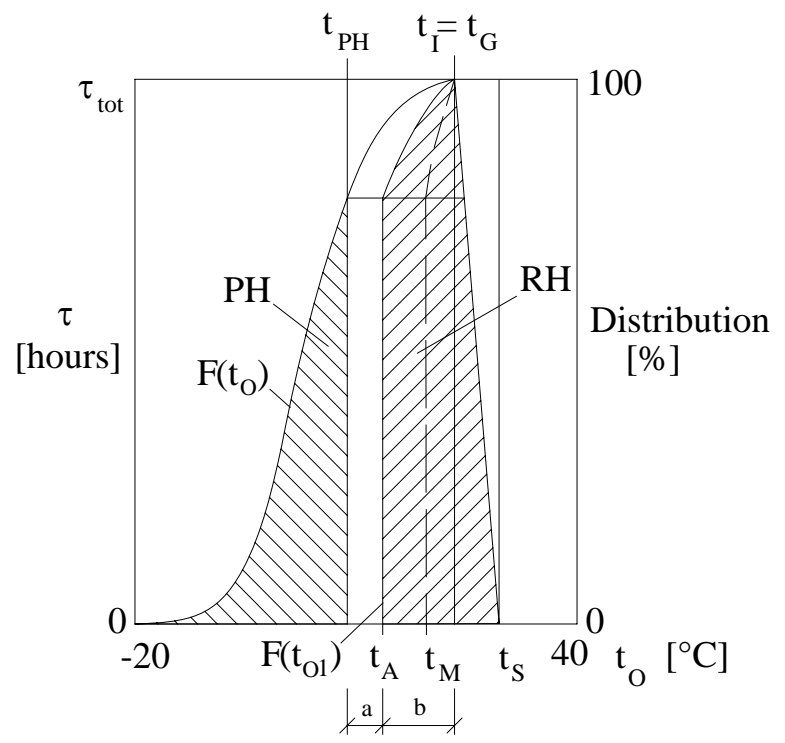

Fig. 6. Air handling unit with pre-heater, by-pass, adiabatic humidifier and re-heater in winter time (REC-AH AHU)

The applied signs on Fig. 6 are the followings:

$\mathrm{t}_{A} ;{ }^{\circ} \mathrm{C}$ : air temperature after the adiabatic humidifier,

$\mathrm{t}_{M} ;{ }^{\circ} \mathrm{C}$ : air temperature after the air mixing.

\section{Energy consumption of pre-heater:}

$$
Q_{P H}=\rho \cdot c_{p a} \cdot \dot{V}_{P H} \cdot \int_{-20}^{t_{P H}} F\left(t_{O}\right) d t \quad ; \mathrm{kJ} / \text { year }
$$

where:

$\dot{V}_{P H} ; \mathrm{m}^{3} / \mathrm{h}:$ air flow rate in pre-heater 
Energy consumption of re-heater:

$Q_{R H}=\rho \cdot c_{p a} \cdot \dot{V}_{R H} \cdot\left[\int_{t_{A}}^{t_{I}} F\left(t_{O 1}\right) d t+\frac{\left(t_{S}-t_{I}\right) \tau_{t o t}}{2}\right] \quad ; \mathrm{kJ} /$ year

where:

$\dot{V}_{R H} ; \mathrm{m}^{3} / \mathrm{h}:$ air flow rate in re-heater

The calculation of heating energy consumption can be seen in the above-mentioned air handling units. Energetic analysis can be made in any air handling units in a similar manner with the help of the presented physical and mathematical methods and equations.

\subsection{Energy consumption of analyzed air handling units}

The energy consumption of four air handling units were analyzed by the developed method. Energetic analysis was made in total heating season which takes from October until March and in the interest of exact energetic calculation was made particularly in a daytime period (07-19 hours) and a nightly period (19-7 hours). The four analyzed air handling units can be seen below:

\section{Fresh air supplied AHU (FAS AHU)}

2 Fresh air supplied AHU with heat recovery (FAS-HR AHU)

3 AHU with air recirculation and adiabatic humidifier (RECAH AHU)

4 AHU with air recirculation and adiabatic humidifier and heat recovery (REC-AH-HR AHU)

The heating energy consumption of the air handling units can be seen in the daytime and nightly period in Fig. 7 and Fig. 8

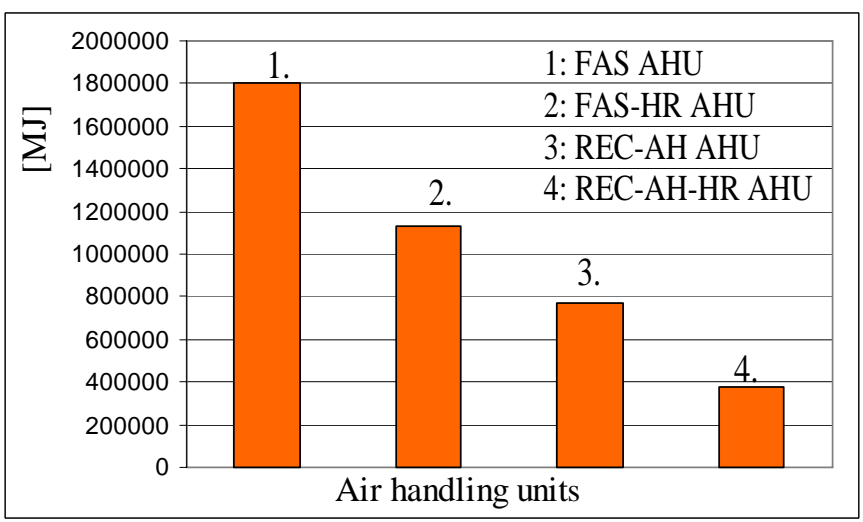

Fig. 7. Heating energy consumption in the daytime from October until March (07-19)

Operation of the AHUs can be seen in Fig. 4 and during the calculation the supply air flow rate was $20000 \mathrm{~m}^{3} / \mathrm{h}$.

\section{Conclusions}

Outdoor air parameters randomly vary from minute to minute. These values can be regarded as a probability variable therefore

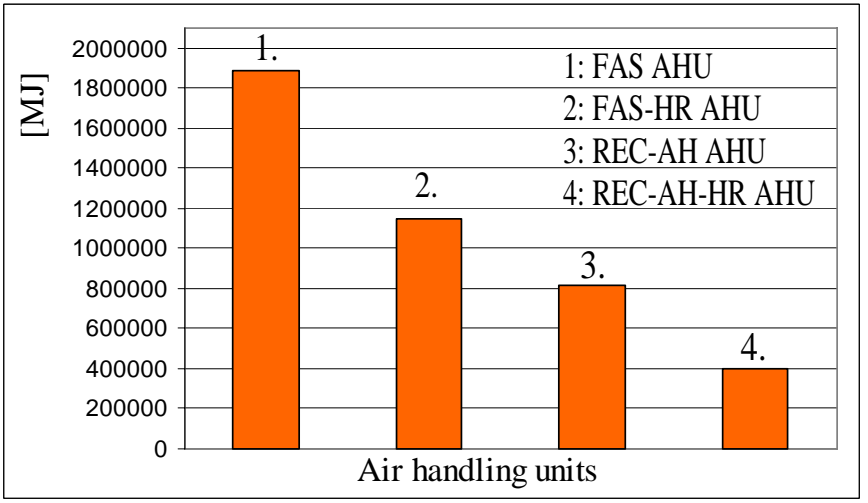

Fig. 8. Heating energy consumption at night from October until March (1907)

energy consumption of air handling units can be determined by probability theory model. In the interest of energetic evaluation of AHUs a probability theory model was developed. The physical and mathematical model was made according to each air handling units.

The developed model is an appropriate method to determine energy consumption of air handling units in annual and in monthly period. Calculations can be made in reference to daytime operation (07-19 hours) and nightly operation (19-7 hours). The mathematical model is based on the distribution functions of outdoor air. These distribution functions can be found in the literature. During our research temperature and enthalpy distribution functions were used that are in reference to Budapest and were average of measured temperatures and enthalpy between 1964-1972. In consequence of changes in the microclimatic conditions outdoor air warming up can be noticed. In our department outdoor air parameters (temperature, humidity) are measured continuously. In this manner energetic analysis can be also made with the current outdoor air parameters.

On the basis of the new theoretical method it was possible to estimate the energy savings for each air handling unit to take into account heat recovery and heat recirculation. Daytime and nightly energy consumptions of the four air handling units have been analyzed by the developed methods from October until March. Results of energetic analysis are presented in Table 1 Results show that energy savings are significant and applying of air-recirculation and heat recovery energy saving can be $79 \%$.

Tab. 1. Rates of energy savings from October until March (00-24 hours)

\begin{tabular}{lcc}
\hline AHU & \multicolumn{2}{c}{ Energy saving } \\
& {$[$ MJ/year] } & {$[\%]$} \\
\hline 1.FAS AHU & 0 & 0 \\
2.FAS-HR AHU & 1417239 & 38 \\
3.REC-AH AHU & 2102541 & 57 \\
4.REC-AH-HR AHU & 2916135 & 79 \\
\hline
\end{tabular}




\section{References}

1 Kajtár L, Klímatechnikai rendszerek energetikai, gazdasági elemzése valószinüség-elméleti alapon, Budapest, 2005.

2 Kajtár L, Kassai M, Levegókezelő központ energiafelhasználásának elemzése valószínüségelméleti módszerrel, Magyar Épületgépészet (2007), no. 4, 3-7.

3 Kajtár L, Gräff J, Kassai M, Központi légkondicionáló berendezések villamos teljesítmény becslésére szolgáló közelító számítási módszer, Gépészet 2008 konferencia CD., pp. 6.

4 Kajtár L, Kassai M, Klímatizált épületek energetikai elemzése, Magyar Épületgépészet (2008), no. 7-8, 3-7.

5 Kajtár L, Vörös Sz, Influence of Climate Change on Modelling of HVAC Systems, 2007. Portoroz, 2nd IASME / WSEAS International Conference on Energy \& Environment, pp. 232-235.

6 Monostory I, Valószínúségelmélet és matematikai statisztika, Múegyetemi Kiadó, Budapest, 2002.

7 Kazuhiro F, Prediction of Energy Consumption by Using Weather Data, 2005 IASME / WSEAS International Conference on Energy, Environment, Ecosystems and sustainable development.

8 Kajtár L, Kassai M, Evaluation of energy demand of air-conditioning systems based on probability theory, 6th IASME/WSEAS International Conference on Heat transfer, Thermal engineering and Environment, 2008, pp. 266300.

9 Kajtár L, Vörös Sz, Risk-Based Modelling of Air-Conditioning System in Hungary, ROOMVENT 2004, 9th International Conference on Air. Book of Abstracts CD 6p., pp. 236-237.

10 Kiss R, Légtechnikai adatok, Múszaki Kiadó, Budapest, 1980.

11 Kajtár L, Klímatechnika - komfort - energetika, Múszaki Kiadványok: Fútés-, hútés- és klímatechnika XI (2008), no. 171, 8-11.

12 Zemljic A, Goricanec D, Krope J, The Recuperation of Waste Heat in the Air Conditioning Systems, The 3rd IASME / WSEAS International Conference on Heat transfer, Thermal engineering and Environment, 2005, pp. 414419. 